NBER WORKING PAPER SERIES

\title{
THE ROLE OF OUTPUT STABILIZATION IN THE CONDUCT OF MONETARY POLICY
}

\author{
Frederic S. Mishkin \\ Working Paper 9291 \\ http://www.nber.org/papers/w9291 \\ NATIONAL BUREAU OF ECONOMIC RESEARCH \\ 1050 Massachusetts Avenue \\ Cambridge, MA 02138 \\ October 2002
}

I thank two anonymous referees for their helpful comments. Any views expressed in this paper are those of the author only and not those of Columbia University or the National Bureau of Economic Research.

(C) 2002 by Frederic S. Mishkin. All rights reserved. Short sections of text, not to exceed two paragraphs, may be quoted without explicit permission provided that full credit, including $(\mathbb{C}$ notice, is given to the source. 
The Role of Output Stabilization in the Conduct of Monetary Policy

Frederic S. Mishkin

NBER Working Paper No. 9291

October 2002

JEL No. E5

ABSTRACT

This paper examines the role of output stabilization in the conduct of monetary policy. It argues that activist monetary policy in which the monetary authorities focus on output fluctuations in the setting of their policy instrument and in policy statements is likely to produce worse outcomes for output and inflation fluctuations, both because it will lead to suboptimal monetary policy, but also because it complicates monetary authorities' communication strategy and can weaken the credibility of the central bank. In contrast, conducting monetary policy with a flexible inflation target rule is likely to produce better outcomes. A flexible inflation target rule also allows the monetary authorities to effectively communicate to the public that they do care about output fluctuations, but makes it less likely that they will be encouraged to try to exploit the short-run tradeoff between output and inflation.

Frederic S. Mishkin

Graduate School of Business

Uris Hall 619

Columbia University

New York, NY 10027

and NBER

fsm3@columbia.edu 
In recent years central banks have increased their focus on price stability, so much so that price stability could be characterized as the central bank mantra. However, the public, politicians and central banks also care about the business cycle. What role does this suggest output stabilization should have in the conduct of monetary policy?

Because standard formulations of the objectives of monetary policy indicate that monetary policy aim at minimizing inflation and output fluctuations, the seemingly obvious answer is that monetary policy which is optimal focuses on output as well as inflation fluctuations. Indeed, the famous Taylor rule suggests exactly this, indicating that the monetary policy authorities should set their interest-rate instrument so that it reacts to deviations of output from its potential as well as to deviations of inflation from its target. However, this paper will argue that this answer is unlikely to be the correct one.

The paper makes the following arguments.

1. Too great a focus on output fluctuations may produce undesirable outcomes: greater fluctuations of output and inflation around their targets.

2. On the other hand, monetary policy that targets inflation is likely to produce better outcomes for both output and inflation fluctuations.

3. In addition, language which stresses output goals can make a central bank's communication strategy less effective and can thereby weaken monetary policy credibility.

4.A communication strategy which instead focuses on the control of inflation is likely to make it easier for the monetary policy authorities to focus on the long run, 
thereby enhancing monetary policy credibility.

The fact that in practice it may be extremely difficult to obtain accurate measures of the output gap, the difference of actual from potential output, provides one rationale for the first two arguments. However, the first two and the remaining arguments are valid even if accurate measures of the output gap could be obtained. This analysis then leads to the following conclusion: despite monetary policymakers' concerns about the business cycle, they will be far more successful in reducing output and inflation fluctuations if they focus less directly on output stabilization and more on inflation stabilization. However, the fact that monetary policymakers downplay the importance of output in their operating procedure does not mean that they are unconcerned about output fluctuations, and there are ways for them to communicate this effectively.

\section{I. Output Fluctuations and the Setting of Monetary Policy Instruments in a Simple Canonical Model}

To clarify the discussion of the role of output fluctuations in the setting of monetary policy instruments, I will make use of a simple, canonical model outlined in Svensson (1997). Despite this model's simplicity it does capture the basic framework that is often used in monetary policy analysis. Furthermore, more complicated models and those with more forward-looking behavior such as the dynamic new Keynesian model in Clarida, Gali and Gertler (1999) yield similar conclusions to those outlined 
here. ${ }^{1}$ The canonical model comprises an aggregate supply curve in which the change in inflation is affected by the output gap with a one period (one year) lag:

$$
\pi_{t}=\pi_{t-1}+\gamma y_{t-1}+\epsilon_{t}
$$

and an aggregate demand curve in which the output gap is a function of the past output gap to reflect persistence and to the real interest rate, again with a one period (one year) lag:

$$
\mathrm{y}_{\mathrm{t}}=\rho \mathrm{y}_{\mathrm{t}-1}-\phi\left(\mathrm{i}_{\mathrm{t}-1}-\pi_{\mathrm{t}-1}\right)+\eta_{\mathrm{t}}
$$

where $\pi_{t}=p_{t}-p_{t-1}=$ the inflation rate at time $t$ (with $p_{t}$ the log of the price level), $y_{t}=$ the output gap (the log of the actual to potential output), $i_{t}=$ the nominal interest rate, and $\epsilon_{\mathrm{t}}$ and $\eta_{\mathrm{t}}$, i.i.d. aggregate supply and demand shocks, respectively.

Optimal monetary policy involves setting the interest rate each period to minimize the intertemporal loss function:

${ }^{1}$ The model in Clarida, Gali and Gertler modifies equations 1 and 2 as follows:

$$
\begin{aligned}
& \pi_{\mathrm{t}}=\beta \mathrm{E}_{\mathrm{t}} \pi_{\mathrm{t}-1}+\gamma \mathrm{y}_{\mathrm{t}-1}+\epsilon_{\mathrm{t}} \\
& \mathrm{y}_{\mathrm{t}}=\mathrm{E}_{\mathrm{y}} \mathrm{y}_{\mathrm{t}+1}-\phi\left(\mathrm{i}_{\mathrm{t}}-\mathrm{E}_{\mathrm{t}} \pi_{\mathrm{t}+1}\right)+\eta_{\mathrm{t}}
\end{aligned}
$$

Given the same loss function in (3) and (4), optimal policy still results in the Taylor rule in (5) because inflation and the output gap are sufficient statistics for the model, i.e., no other variables enter the aggregate supply and demand functions. Note however, that the coefficients in the Taylor rule equation will differ depending on the degree of forward-looking behavior. 


$$
\mathrm{E}_{\mathrm{t}} \sum_{\tau=\mathrm{t}}^{\infty} \delta^{\tau-\mathrm{t}} \mathrm{L}_{\tau}
$$

where $\delta<1$ is the authorities' discount rate and where the period-by-period loss function is:

$$
\mathrm{L}_{\tau}=\left(\pi_{\tau}-\pi^{*}\right)^{2} / 2+\lambda \mathrm{y}_{\tau}^{2} / 2
$$

The optimal setting of the interest rate is then a "Taylor rule",

$$
\mathrm{i}_{\mathrm{t}}=\pi_{\mathrm{t}}+\mathrm{b}_{1}\left(\pi_{\mathrm{t}}-\pi^{*}\right)+\mathrm{b}_{2} \mathrm{y}_{\mathrm{t}}
$$

in which the interest rate responds to both the inflation gap, $\pi_{t}-\pi^{*}$, and the output gap, $y_{t}$.

This simple model illustrates several important points. First, this model indicates that monetary policy should focus on output fluctuations for two reasons. Even if $\lambda=0$ so that the monetary authority does not care about output fluctuations and so can be characterized as an "inflation nutter" [King, 1996], the $b_{2}$ coefficient on the output gap in the Taylor rule will still be positive. This is because the output gap enters the aggregate supply curve in (1) and therefore helps forecast future inflation. Thus optimal monetary policy, even if the focus is solely on hitting an inflation target and not at all on output fluctuations, still reacts to the state of the business cycle, as reflected in the output gap $\mathrm{y}_{\mathrm{t}}$. Another reason for monetary policy focusing on output fluctuations arises when minimizing output fluctuations is important to the monetary authority so 
that $\lambda>0$. Then the $b_{2}$ coefficient will be even larger. Indeed, case studies of the behavior of monetary authorities who pursue inflation targeting described in Bernanke, et. al. (1999) do suggest that they care about output fluctuations, which of course makes sense because the general public surely cares about the tradeoff between output and inflation fluctuations.

Instead of characterizing optimal monetary policy with what Svensson (1999) has called an "instrument rule" like the Taylor rule in equation (5) above, optimal monetary policy can described by a "target rule" in which the setting of forecasted variables relative to a target is specified. In the case of $\lambda=0$ in the simple model here, Svensson (1997) has shown that setting the optimal setting of the interest rate according to equation (5) is equivalent to setting the interest rate so that the following target rule is followed:

$$
\mathrm{E}_{\mathrm{t}} \pi_{\mathrm{t}+2}=\pi^{*}
$$

In other words, the monetary policy instrument is set so as to attain the inflation target over the policy horizon, which in this model is two periods (years) ahead. If $\lambda>0$, so that monetary policymakers are also concerned abut output fluctuations, then the interest rate instrument is also set according to equation (5), which is equivalent to following a target rule in which the approach to the inflation target is more gradual, i.e.,

$$
\mathrm{E}_{\mathrm{t}} \pi_{\mathrm{t}+2}-\pi^{*}=\mathrm{c}\left(\mathrm{E}_{\mathrm{t}} \pi_{\mathrm{t}+1}-\pi^{*}\right)
$$

Svensson (1997) calls this type of policy reaction "flexible inflation targeting", and the 
evidence discussed in Bernanke et al. (1999) suggests that it is a realistic approximation of what inflation targeting countries do in practice.

In the simple model outlined here, the instrument rule in (5) is equivalent to the target rules in (6)--if $\lambda=0$-- or (7)--if $\lambda>0$. Output fluctuations influence the setting of the monetary policy instrument for either of two reasons. First, output fluctuations matter because they affect the forecast of future inflation, even if policymakers do not care about minimizing output fluctuations in their objectives $(\lambda=0)$. Indeed, in this canonical model the only way that policymakers can control inflation is by manipulating the output gap. Second, output fluctuations affect the setting of the monetary policy instrument because policymakers do care about minimizing output fluctuations $(\lambda>0)$, and so it is optimal to approach the inflation target more slowly. Hence either the instrument rule or the target rule leads to the obvious conclusion that monetary policy should be "activist", i.e., it should respond actively to deviations of output from its potential.

\section{II. \\ Criticisms of the Canonical Model and its Elements}

Although the canonical model produces important insights, it can be criticized on the grounds that the world is not so simple it suggests. If other variables affect the aggregate demand or supply equations, then the Taylor rule in (5) will no longer be optimal, while the target rules in (6) or (7) will. This is a key reason why Svensson and others take the position that target rules have inherent advantages over instrument rules. As argued by Bernanke et al (1999) and Mishkin (1999), target rules also have important advantages in communicating with the public, an issue we will return to in 
the next section.

The world is also complicated by the fact that it may be quite difficult to measure the output gap, $\mathrm{y}_{\mathrm{t}}$. There are two reasons why measuring the output gap is so difficult. The first is that it is hard to measure potential output and the second is that it is not at all clear what is the proper theoretical concept of the output gap.

\section{A. Potential Output Measurement is Hard to Do}

One measurement problem occurs because monetary policy authorities have to estimate the output gap with real-time data, i.e., data that is available at the time they set the policy instrument. GDP data is frequently revised substantially and this is one reason why output gaps are mismeasured in real time. Even more important: it is notoriously hard to know what potential GDP actually is without hindsight. For example, it was not until the 1980s, that policymakers recognized that potential GDP growth had slowed markedly after 1973. Orphanides (2001) shows that the errors in measures of output gaps have been very large in the postwar period, while Orphanides (1998) shows that the use of real-time data might lead to such inaccurate estimates that active monetary policy which reacts strongly to output fluctuations actually increases economic instability. Indeed, Orphanides (2002) argues that the reason for the Federal Reserve's poor performance during the 1970s was not that it was unconcerned with inflation, but rather that it was too activist, i.e., it had a large weight on output gaps in its Taylor-rule reaction function. Orphanides work thus indicates that even though monetary policy which is set optimally should react actively to the output gap if it were correctly estimated, too large a focus on the output fluctuations actually leads to worse 
economic outcomes.

\section{B. What is the Proper Concept of the Output Gap?}

A second measurement problem occurs because conceptually the $y_{t}$ that belongs in the aggregate supply curve in equation (1) is not at all clear and may be quite different from conventionally measured output gaps. Clarida, Gali and Gertler point out that new Keynesian aggregate supply curves should have $y_{t}$ specified as a marginal cost measure rather than an output gap and they find that the marginal cost measure has substantially different movements and timing than the conventionally measured output gap. McCallum and Nelson (2000) and McCallum (2001) argue that conventionally measured output gaps which estimate the gap as deviations from a trend differ substantially from more theoretically grounded measures based on the output level that would prevail in the absence of nominal price stickiness. They find that monetary policy rules which react to conventional output gap measures produce excessive volatility of output and inflation.

Empirical evidence also questions the usefulness of the relying on the output gap to forecast inflation (Atkenson and Ohanian, 2001). Estrella and Mishkin (1999) also find that Taylor rules which are based on conventional output gaps do not take sufficient account of other factors affecting the inflation process and would have led to monetary policy which was far too tight in the last half of the 1990s. Conventional views of the output gap suggested that the Federal Reserve should have tightened monetary policy considerably in the late 1990s as the unemployment rate fell well below the $6 \%$, the level below which most economists at the time thought would lead to 
accelerating inflation. Alan Greenspan, the chairman of the Fed, resisted this view because his reading of the data did not suggest inflationary pressures in the economy. The result was that the Fed kept interest rates low, thus helping promote the longest business cycle expansion in U.S. history, along with a decline in inflation to levels that are consistent with price stability.

One way of characterizing the success of the Greenspan Fed in the 1990s is that it operated more from the perspective of the target rule in (7) rather than from the instrument rule in (5). The Greenspan Fed recognized that standard measures of potential output gap were possibly inaccurate and that measures of the output gap were probably overestimated. The Fed was thus more cautious in relying on output gap models and instead concentrated on developments on the inflation front in its conduct of policy. As a result, it was unwilling to reign in a rapidly growing economy if it was not leading to a rise in inflation. In other words, instead of focusing on output gaps, the Fed kept its focus on the inflation ball, and this was a key factor in its success in the late 1990s.

\section{III. Communicating the Policy Process}

The analysis above suggests that because output gaps are hard to measure, too great a focus on output fluctuations in the setting of monetary policy instruments is undesirable because it is likely to lead to greater inflation and output variability. Focusing on output fluctuations can be undesirable for another reason: it can make the communication process of the monetary authorities less effective which can also lead to 
worse economic outcomes. Indeed, even if output gaps could be measured accurately, it still might be undesirable for the monetary authorities to focus on output fluctuations in setting monetary policy because of the harm it would do to the communication process. The argument for a deemphasis on the discussion of output stabilization in communicating monetary policy rests on the benefits its provides in terms of a focus on the long run, enhancing monetary policy credibility and simplifying communication and transparency. This does not mean that central banks will not indicate to the public that they care about output fluctuations, but they can do so in the context of outlining how they will pursue inflation stabilization.

\section{A. Long-Run Focus}

The optimizing framework in the previous section assumes that the monetary authorities are able to avoid the time-inconsistency problem and can commit to either target or instrument rules. This framework does involve the monetary authorities taking account of both output and inflation fluctuations in their objective function, but rules out exploitation of short-run tradeoffs between output growth and inflation which is the crux of the time-inconsistency problem. As I have emphasized in Mishkin (1999, 2000), the source of the time-inconsistency problem is rarely inside the central bank because central bankers understand that trying to exploit short-run tradeoffs will only produce worse long-run outcomes. However, the time-inconsistency problem is highly relevant to the conduct of central banking because politicians have incentives to pursue short-run interests and put political pressure on central banks to exploit the short-run tradeoff between output and inflation, thereby resulting in overly expansionary 
monetary policy.

Thus an important issue is how can monetary authorities minimize the timeinconsistency problem? A successful communication strategy is a key part of the answer. In order to avoid political pressures to pursue short-run tradeoffs, central banks need to focus the debate on what a central bank can do in the long run -- control inflation -- rather than what it cannot do on a sustainable basis -- raise economic growth through expansionary monetary policy. A focus on output fluctuations in discussing the conduct of monetary policy, is likely to make it harder to achieve this objective. When monetary authorities explain their monetary policy actions by referring to the need to moderate swings in output growth, the political debate about monetary policy is likely to focus on short-run issues such as, whether the central bank is doing enough to create jobs and lower unemployment, or whether its policies are anti-growth. Indeed, in the past, the political debate has frequently taken on these features in the United States.

To get the political debate to focus on longer-run issues, central banks have used several communication strategies. The Bundesbank before the creation of the European Monetary Union (when it had its own independent monetary policy) couched the discussion of monetary policy in terms of monetary aggregate targets, and it was considered to be one of the most successful central banks in the world. A key feature of the German monetary targeting regime was that the calculation of the monetary target ranges was a very public exercise that focused on long-run issues (see Bernanke and Mishkin, 1992, Laubach and Posen, 1997, and Mishkin and Posen, 1997). First, a numerical inflation goal was prominently featured in the setting of the target ranges. Then with estimates of potential output growth and velocity trends, a quantity-equation 
framework was used to back out target growth rates for the monetary aggregates. An important feature of this calculation was that potential GDP trends were used rather than actual GDP, thus reflecting the Bundesbank's articulated position that it should focus on long-run considerations, particularly price stability, rather than on short-run output fluctuations.

Central banks in countries that have adopted inflation targeting also put a lot of effort into getting the public to focus on long-run goals of monetary policy, as documented by Bernanke et al (1999). Instead of articulating monetary policy in terms of an instrument rule and potential reactions to output fluctuations, monetary policy is discussed in the context of a target rule like equation (7) in which achievement of the inflation goal is emphasized. Particularly noteworthy in this regard are the publication of Inflation Reports. These documents explain to the general public the long-run goals and limitations of monetary policy, the rationale for inflation targets, and how monetary policy has to be forward-looking in order to achieve these targets. They and other communications of the central bank, including speeches, testimony to the legislature and even glossy brochures, have been able to shift the debate on monetary policy away from a focus on short-run job creation to longer run considerations.

A remarkable episode in Canada in the aftermath of a speech in 1996 by the president of the Canadian Economic Association, Fortin (1996), discussed in Mishkin (1999) and Bernanke et al (1999), illustrates how successful such a strategy can be in shifting the public debate away from a short-run focus. The speech, criticized the Bank of Canada for pursuing overly contractionary monetary policy and it sparked off a widespread public debate. What was remarkable was that the communication strategy embodied in the inflation targeting regime was able to channel the debate into a 
substantive discussion over what should be the appropriate target of inflation, with the Bank defending its 1 to $3 \%$ target range, while Fortin ended up advocating a 2 to $4 \%$ range. This debate which involved discussion of the costs and benefits of different levels of inflation, thus became focused on the long-run goals of monetary policy, which is exactly where such a debate should be focused in order for the time-inconsistency problem is to be avoided.

\section{B. Credibility}

A second problem with discussing monetary policy in terms of its reaction to output fluctuations is that it can have undesirable consequences for central bank credibility. A focus on output fluctuations may lead economic agents to believe that the monetary authorities will try to eliminate any decline in output below potential. As a result, it is more likely that workers and firms will raise wages and prices because they know that the monetary authorities are likely to accommodate these rises by pursuing expansionary policy to prevent unemployment from developing. The result is that a self-fulfilling equilibrium can occur in which wages and prices rise, then monetary policy accommodates this rise, and this leads to further rises in wages and prices, and so on, thus leading to a new equilibrium with higher inflation without a reduction in output fluctuations. Chari, Christiano and Evans (1998) have described this bad equilibrium as an "expectation trap."2 Discussing monetary policy objectives in terms of output fluctuations can thus lead to a loss of inflation-fighting credibility for the central bank, with the result that the inflation-output fluctuations tradeoff worsens.

\footnotetext{
${ }^{2}$ I made a similar argument in the first and later editions of my textbook, Mishkin (1986), but it was not until Chari, Christiano and Eichenbaum (1998) that the argument was formalized.
} 


\section{Simplifying Communication and Transparency}

A third problem with monetary authorities discussing output fluctuations in the conduct of monetary policy is that it complicates their communication strategy. The KISS principle ("Keep It Simple Stupid") suggests that monetary policy should be articulated in as simple a way as possible. The beauty of inflation target regimes is that by focusing on one objective -- inflation -- communication is fairly straightforward. On the other hand, when there are two objectives, the public is likely to get confused. Discussion of output as well as inflation objectives is thus likely to obscure the transparency of monetary policy and make it less likely that the public will support a monetary policy that focuses on long-run considerations, which is so necessary to successful monetary policy performance. ${ }^{3}$

\section{How Can Central Banks Communicate That They Care About Output Fluctuations?}

The conclusion from the above analysis is that too much focus on output fluctuations in discussions of monetary policy is likely to worsen economic performance. But we have already seen that central banks do care about output fluctuations in their objective function, which was described in equations (3) and (4). How can monetary authorities convince the public that they are not "inflation nutters",

\footnotetext{
${ }^{3} \mathrm{~A}$ similar argument has been made by many critics, myself included, against the two pillar strategy of the
European central bank: that it is confusing to the public.
} 
which may be very important to retaining support for the central bank and its policies. The answer is that the central bank can discuss the setting of its policy instruments in terms of the target rule in (7). It would do this by indicating that it will not try to hit its inflation target over too short a horizon because this would result unacceptably high output losses. Indeed, inflation-targeting central banks have been moving in exactly this direction: for example, the Reserve Bank of New Zealand which has modified its inflation-targeting regime to lengthen the horizon over which it tries to achieve its inflation target. ${ }^{4}$ Monetary authorities can further the public's understanding that they care about reducing output fluctuations in the long run by emphasizing that monetary policy needs to be just as vigilant in preventing inflation from falling too low as it is from preventing it from being too high. Indeed, an explicit inflation target may help the monetary authorities stabilize the economy because they can be more aggressive in easing monetary policy in the face of negative demand shocks to the economy without being concerned that this will cause a blowout in inflation expectations. However, in order to keep the communication strategy clear, the explanation of a monetary policy easing in the face of negative demand shocks needs to indicate that it is consistent with the preservation of price stability.

\section{IV. \\ IMPLICATIONS FOR THE FEDERAL RESERVE}

Although the Federal Reserve has not adopted inflation targeting and has no explicitly announced inflation goal, it nonetheless has emphasized the price stability

\footnotetext{
${ }^{4}$ See Sherwin (1999), Drew and Orr (1999) and Reserve Bank of New Zealand (2000).
} 
goal for monetary policy. Indeed, a fair characterization of the Federal Reserve under Alan Greenspan, is that it has been acting in accordance with the optimizing framework described in Section I and that it has not put too much emphasis on output fluctuations in the conduct of monetary policy. Starting in February 1994, the Greenspan Fed began raising the federal funds rate, its policy instrument, in order to preemptively head off a rise in inflation. These actions were completely consistent with the inflation target rule that the central bank set the interest rate instrument to keep inflation near its target several years down the road. Then as was mentioned earlier, in the late 1990s, the Fed refrained from raising interest rates even when output appeared to be rising above potential output because it was focusing on inflation control and yet it was unclear that inflation pressures were building up. This is exactly what following an inflation target rule would have prescribed for Federal Reserve behavior.

It is also not clear that the Federal Reserve has any less inflation-fighting credibility than other central banks which have adopted inflation targeting. Thus, we seem to be in a situation of "if it ain't broke, why fix it." However, one concern that I have raised elsewhere in Mishkin (2000) is that the Fed's credibility is very much based on individual personalities. Alan Greenspan is a highly effective nominal anchor in the United States currently, but unfortunately he will not be around forever. In addition, the Greenspan Fed has been operating in a particularly favorable political environment in recent years. There has been tremendous cooperation between the U.S. Treasury and the Federal Reserve, while both President Bush and Clinton have refrained from criticizing the Fed, in contrast to some earlier presidents. Furthermore, government fiscal policy has been favorable for monetary policymaking (at least up until recently), with budget surpluses or small deficits. When Greenspan steps down from the 
chairmanship of the Fed and if the political environment for monetary policy deteriorates, the credibility of the Fed and its ability to pursue its price stability goal might be severely compromised.

The argument above suggests that developing an institutional basis for the way the Greenspan Fed has been conducting monetary policy would help promote better outcomes for inflation and output fluctuations in the future. This is indeed the rationale for the Federal Reserve to move in the direction of more explicit inflation targeting. However, it also raises concerns about the Fed's current communication strategy, specifically in the way it announces its policy stance at the conclusion of every FOMC meeting. Currently, with the announcement of the federal funds rate target, the Fed provides the so-called "bias" or "balance of risks" statement in which it states that the balance of risks are balanced, or are "mainly toward conditions that may generate inflation pressures in the foreseeable future," or are "mainly toward conditions that may generate economic weakness in the foreseeable future." When there is a long period of time in which the statements have a balance of risks toward economic weakness in the economy, it may encourage the public to believe that the Fed has shifted to a short-run focus on preventing economic downturns.

Since its FOMC meeting in January 2001, when the Fed indicated that the balance of risks was toward economic weakness, most of its statements have continued to indicate that the risks are to economic weakness. Indeed, for nearly two years (as of date of this writing), none of the Fed's statements have indicated that there are concerns about inflationary pressures. The absence in the balance of risk statements of concerns about inflation have the potential to weaken the Fed's credibility as an inflation fighter in the future and it might lead to less concern in political circles about inflation control. 
This could lead in the future to increased political pressure on the Fed to pursue shortterm rather than long-term policies. Neither of these problems might be severe while Alan Greenspan remains at the Fed, but when he departs, they could lead to a worsening of the tradeoff between output and inflation fluctuations, thereby worsening economic performance.

One solution to the above problem might be to eliminate the balance-of-risks statement, but this statement does have value in enhancing the transparency of Federal Reserve policymaking. In addition, it also allows members of the FOMC to reach consensus when there is some disagreement about whether to change the federal funds rate: possible dissenters may be willing to vote with the majority if the FOMC adopts a balance-of-risks statement which suggests a future change in interest rates in the direction that they would like to see. Another solution is to modify the balance-of-risks statement to put more focus on the price stability goal of the Fed. For example, the balance-of-risks when the risk is of higher inflation in the future could still remain as "mainly toward conditions that may generate inflation pressures in the foreseeable future." But if the risk is to weakness in the economy the statement could be modified to be "mainly toward conditions that may generate deflationary pressures in the foreseeable future." This is quite a small change in the communication strategy of the Fed, but when the Fed is ready to reverse course and raise interest rates to head off future inflation, having the balance-of-risks statement always focus on inflationary pressures might enhance Federal Reserve credibility and political support for inflation control. 


\section{V. \\ CONCLUSIONS}

An important issue for monetary policymakers is how activist they should be, that is, to what extent they should focus on output fluctuations in the conduct of monetary policy? The debate on this question is an old one, and the answer that Milton Friedman gave many years ago (e.g., Friedman, 1968) was that activism would worsen monetary policy performance. Developments in the monetary economics field in recent years lead to the same answer. This paper argues that an activist monetary policy is likely to worsen the tradeoff between output and inflation fluctuations, both because it will lead to suboptimal monetary policy, but also because it complicates monetary authorities' communication strategy and can weaken the credibility of central banks. The bottom line is that for the monetary authorities to be successful in minimizing output and inflation fluctuations, they must never take their eye off the inflation ball. This is why continual repeating of the central bank mantra of price stability will not only be good for the soul, but for the economy as well. 


\section{References}

Atkenson, Andrew and Lee E. Ohanian (2001), "Are Phillips Curves Useful for

Forecasting Inflation?" Federal Reserve Bank of Minneapolis Quarterly Review 25, 1 (Winter): 2-11.

Bernanke, Ben S., Laubach, Thomas, Mishkin, Frederic S. and Adam S. Posen (1999), Inflation Targeting: Lessons from the International Experience, Princeton, NJ: Princeton University Press.

Bernanke, Ben S. and Frederic S. Mishkin (1992), "Central Bank Behavior and the Strategy of Monetary Policy: Observations from Six Industrialized Countries," In Olivier Blanchard and Stanley Fischer, eds., NBER Macroeconomics Annual (Cambridge, Mass.: MIT Press): 183-238.

Chari, V.V., Christiano, Lawrence J. and Martin Eichenbaum (1998), "Expectation Traps and Discretion," Journal of Economic Theory, vol. 81, no. 2): 462-92.

Clarida, Richard, Gali, Jordi and Mark Gertler (1999), "The Science of Monetary Policy," Journal of Economic Literature, Vol. 34, No. 4 (December): 1661-1707.

Drew, Aaron and Adrian Orr (1999), "The Reserve Bank's Role in the Recent Business Cycle: Actions and Evolution," Reserve Bank of New Zealand Bulletin, 62, No. 1. 
Estrella, Arturo and Frederic S. Mishkin (1999), "The Role of NAIRU in Monetary

Policy: Implications of Uncertainty and Model Selection," in John Taylor, ed., Monetary Policy Rules (University of Chicago Press for the NBER: Chicago): 405-430.

Fortin, Pierre (1996), "The Great Canadian Slump," Canadian Journal of Economics, Vol. 29: 761-87.

Friedman, Milton (1968), "The Role of Monetary Policy," American Economic Review Vol. 58: 1-17.

Gali, Jordi and Mark Gertler (1999), "Inflation Dynamics: A Structural Econometric Analysis," Journal of Monetary Economics, Vol. 44, No. 2 (October): 195-222.

King, Mervyn (1996). "How Should Central Banks Reduce Inflation?- Conceptual Issues," in Achieving Price Stability, Federal Reserve Bank of Kansas City, Kansas City, MO: 53-91.

Laubach, Thomas and Adam S. Posen (1997), "Disciplined Discretion: Monetary Targeting in Germany and Switzerland," Essays in International Finance no. 206, (December) (International Finance Section, Princeton University)

McCallum, Bennett T. (2001), "Should Monetary Policy Respond Strongly to Output Gaps?" American Economic Review, Vol. 91 (May): 258-62. 
McCallum, Bennett T. and Edward Nelson (2000), "Timeless Perspective vs.

Discretionary Monetary Policy in Forward-Looking Models," NBER Working Paper No. 7915 (September).

Mishkin, Frederic S. (1986), The Economics of Money, Banking, and Financial Markets (Little Brown and Co.: Boston)

Mishkin, Frederic S. (1999), "International Experiences with Different Monetary Policy Regimes," Journal of Monetary Economics, Vol. 43, \#3 (June): 579-606.

Mishkin, Frederic S. (2000), "What Should Central Banks Do?" Federal Reserve Bank of St. Louis Review, vol. 82, \#6 (November/December): 1-13.

Mishkin, Frederic S. and Adam S. Posen (1997), "Inflation Targeting: Lessons from Four Countries," Federal Reserve Bank of New York, Economic Policy Review, vol. 3, \#3 (August): 9-110

Orphanides, Athanasios (1998), "Monetary Policy Evaluation with Noisy Information," Federal Reserve Board FEDS paper No. 98-50 (October).

Orphanides, Athanasios (2001), "Monetary Policy Rules Based on Real-Time Data," American Economic Review, Vol. 91, No. 4 (September): 964-85. 
Orphanides, Athanasios (2002), "Monetary Policy Rules and the Great Inflation," American Economic Review, 92(2) (May): 115-120.

Reserve Bank of New Zealand (2000). Monetary Policy Statement, March 2000, Reserve Bank of New Zealand, Wellington, New Zealand.

Sherwin, Murray (1999). "Inflation Targeting: 10 Years On," Speech to New Zealand Association of Economists Conference, Rotorua, New Zealand, July 1.

Svensson, Lars E.O. (1997), "Inflation Forecast Targeting: Implementing and Monitoring Inflation Targets," European Economic Review, 41: 1111-1146.

Svensson, Lars E.O. (1999), "Inflation Targeting as a Monetary Policy Rule," Journal of Monetary Economics, Vol. 43, No. 3 (June): 607-654. 